\author{
Alain Cariou \\ Jerry P. Nolan \\ Kjetil Sunde
}

\section{Neuroprotection and cardioprotection after cardiac arrest: how cool is cool enough? Response to Polderman}

Accepted: 15 May 2015

Published online: 3 June 2015

(C) Springer-Verlag Berlin Heidelberg and ESICM 2015

\section{Dear Editor,}

We thank Dr. Polderman for his interest and comments on our suggested strategies to increase survival from cardiac arrest $[1,2]$. We indicated that there remains debate about whether 33 or $36{ }^{\circ} \mathrm{C}$ is the optimal target during temperature control after cardiac arrest. Until recently, the $33{ }^{\circ} \mathrm{C}$ target was the most commonly used in clinical practice, probably because this was in the middle of the target range $\left(32-34{ }^{\circ} \mathrm{C}\right)$ for the interventional arm of the Hypothermia After Cardiac Arrest (HACA) trial [3], but the TTM trial recently challenged this target [4]. We agree that on the basis of all the available data, when treating comatose post cardiac arrest patients with temperature control, a constant target temperature in the range 32-36 ${ }^{\circ} \mathrm{C}$ should be recommended. This is also consistent with the recent draft treatment recommendation made by the Advanced Life Support Task Force of the International Liaison Committee on Resuscitation (ILCOR) [5]. We await the results of ongoing studies that will provide more data on timing, duration and depth of targeted temperature management.

\section{References}

1. Polderman KH (2015) Neuroprotection and cardioprotection after cardiac arrest: how cool is cool enough? Intensive Care Med. doi:10.1007/s00134-015-3842-x
2. Cariou A, Nolan JP, Sunde K (2015) Ten strategies to increase survival of cardiac arrest patients. Intensive Care Med. doi: 10.1007/s00134-015-3788-z

3. Hypothermia After Cardiac Arrest Study Group (2002) Mild therapeutic hypothermia to improve the neurologic outcome after cardiac arrest. N Engl J Med 346:549-556

4. Nielsen N, Wetterslev J, Cronberg T, Erlinge D, Gasche Y, Hassager C, Horn J, Hovdenes J, Kjaergaard J, Kuiper M, Pellis T, Stammet P, Wanscher M, Wise MP, Aneman A, Al-Subaie N, Boesgaard S, Bro-Jeppesen J, Brunetti I, Bugge JF, Hingston CD, Juffermans NP, Koopmans M, Køber L, Langørgen J, Lilja G, Møller JE, Rundgren M, Rylander C, Smid O, Werer C, Winkel P, Friberg H, Trial Investigators TTM (2013) Targeted temperature management at $33{ }^{\circ} \mathrm{C}$ versus $36{ }^{\circ} \mathrm{C}$ after cardiac arrest. N Engl J Med 369:2197-2206

5. Advanced Life Support Task Force of the International Liaison Committee on Resuscitation (2015)

http://www.ilcor.org/seers. Accessed 1 Jan 2015

A. Cariou (®) · J. P. Nolan · K. Sunde Medical Intensive Care Unit, 27 rue du faubourg Saint-Jacques, 75679 Paris Cedex 14, France e-mail: alain.cariou@cch.aphp.fr Tel.: 33158412707 